\title{
Behavioral specialization among group members in the captive mandarin vole, Lasiopodomys mandarinus (Rodentia, Arvicolidae)
}

\author{
Antonina V. Smorkatcheva \& Ekaterina S. Smolnyakova
}

\begin{abstract}
Group-living and cooperative breeding in the mandarin vole Lasiopodomys mandarinus were proposed to be an adaptation (or preadaptation) to the fossorial mode of life (Smorkatcheva, 1999). This hypothesis involved indirect benefits that gain offspring by helping their mother in tunnel construction among the factors promoting cooperative breeding. Answer to the question "which animals do provide the most help?" may allow us to understand whether helpers derive direct or indirect benefits from their action. In this study we compared the contributions to nest-residence, digging, bringing objects, eating and the digging/ eating rates between different sex-age categories. We observed groups composed of pair of breeders, 1-9 weaned offspring and unweaned pups in artificial tunnel systems. Only daughters older 35 days participated extensively (along with their fathers) in transport and burrow construction. Overall, the digging/eating rate was greater in daughters than in mothers. This provides evidence that young females perform some excess workload to be used up, potentially, by reproductive female. Sons, independently of their age, and daughters under 35 days were engaged very little (lesser than other members of families) in burrow construction and transport. Sons under 60 days, daughter older 60 days and fathers were the major baby-sitters. Sex differences in degree of the most expensive activities are inconsistent with the kin-selection hypothesis, but can be explained in the framework of delayed reciprocity or group augmentation hypothesis. Another (nonalternative) explanation of the revealed sex-bias is that burrow construction would be parental, not only alloparental, investment for daughter should it attain a breeding position at natal territory.
\end{abstract}

KEY WORDS: Lasiopodomys mandarinus, subterranean rodent, cooperative breeding, sex-biased helping.

Antonina V. Smorkatcheva [tonyas1965@mail.ru], Department of Vertebrate Zoology, St. Petersburg State University, Universitetskaya nab. 1, St. Petersburg 199034 Russia; Ekaterina Smolnyakova, Department of Vertebrate Zoology, St. Petersburg State University, Universitetskaya nab. 1, St. Petersburg 199034 Russia.

\section{Поведенческая специализация среди членов семейных групп у китайской полевки Lasiopodomys mandarinus (Rodentia, Arvicolidae) при содержании в неволе}

\section{А.В. Сморкачева, Е.С. Смольнякова}

РЕЗЮМЕ. Групповой образ жизни и кооперативное размножение у китайской полевки рассматривались как адаптация (или преадаптация) к подземному образу жизни (Smorkatcheva, 1999). По этой гипотезе, одним из факторов, способствующих кооперативному размножению, является непрямая выгода, которую потомство получает, помогая матери в норостроении. Информация о том, кто именно и в каком объеме помогает, иногда позволяет отделить прямую выгоду от непрямой. В этой работе мы сравнивали затраты времени на нахождение в гнезде с детенышами, копание и еду, соотношение затрат на копание и еду (индекс D/E), а также частоту доставки объектов в нору для разных поло-возрастных категорий. Наблюдались сложные группы, помещенные в систему стеклянных коридоров и камер. Активное участвовалив норостроении и доставке объектов только дочери старше 35 дней и отцы. В целом, индекс D/E был у дочерей был выше, чем у матерей. Следовательно, молодые самки совршают некоторую избыточную “работу”, результаты которой, потенциально, могут быть использованы размножающимися самками. Сыновья любого возраста и дочери моложе 36 дней очень мало (меньше, чем остальные члены группы) участвовали в норостроении и транспорте. Сыновья до 60 дней, дочери старше 60 дней и отцы проводили в гнезде больше времени, чем другие члены группы. Половые различия в уровне наиболее дорогих видов деятельности противоречат гипотезе родственного отбора (kin-selection), но могут быть объяснены в рамках гипотезы отсроченной реципроктности (delayed reciprocity or group augmentation). Другое (не альтернативное) объяснение неравного вклада полов в норостроение состоит в том, что в случае филопатрического размножения, возможного лишь для самок, этот вклад является родительским, а не аллопарентным.

КЛЮЧЕВЫЕ СЛОВА:Lasiopodomys mandarinus, подземные грызуны, кооперативное размножение, половые различия в уровне помощничества. 


\section{Introduction}

The cooperative breeding has been documented for at least 120 species of mammals (Krebs \& Davies, 2000) and 35 species of rodents (Solomon \& Getz, 1997). A number of hypotheses have been proposed to account for the evolution of cooperative breeding and helping behavior (Skutch, 1961; Hamilton, 1964; Gaston, 1978; Ligon \& Ligon, 1978; Jamieson, 1989). Cooperation can evolve in several ways: by kin-selection, mutualism, manipulation or reciprocity, but it is often very difficult to distinguish between these possibilities (Krebs \& Davies, 2000; Clutton-Brock, 2002). Answer to the question "which animals do provide the most help?" may allow us to understand whether helpers derive direct or indirect benefits from their action (Brotherton et al., 2001). Meanwhile, almost no studies of cooperative rodents have quantified the contributions made by different members of group.

Apparently, the best-studied examples of social rodents are bathyergid mole-rats in the genera Heterocephalus and Cryptomys. These curious subterranean animals live in colonies composed of a reproductive pair and a number of non-reproductive workers, which contribute to digging, searching for food, guarding or brooding young. Their most striking feature is a division of labor between non-breeders (Jarvis, 1981; Bennett \& Jarvis, 1988; Bennett, 1989; Moolman et al., 1998). It has been suggested that the difficulty of constructing elaborative burrow system combined with reproductive constraints phyloginetically determined in hystricognathous rodents was responsible for evolution towards eusociality in these species (Burda, 1990; Burda et al., 2000). Among sciurognathous subterranean rodents cooperative breeding has been reported only in a few members of subfamily Arvicolinae (Fitzgerald \& Madison, 1983; Smorkatcheva et al., 1990; Power \& Fried, 1992; Zorenko et al., 1994; Evdokimov, 2000; Lacey, 2000). Subterranean arvicolines might constitute a convenient model group for comparative investigations of cooperative breeding and its relation to the fossorial mode of life. However, to date the behaviors of helpers have been quantified for the only species, Microtus pinetorum (Powell \& Fried, 1992).

The mandarin voleLasiopodomys mandarinus leads an almost completely subterranean existence and digs extensive tunnel systems to forage for geophytes as well as aerial parts of plants. It is a facultative cooperative breeder. During the reproductive period, each burrow system is occupied by a family groups, which consist of one breeding male, one to five breeding females and young of one to three generations, up to 22 as maximum. Young typically remain at their natal territory at least up to 45-50 days and some of them even up to 70 days (Smorkatcheva, 1999). Despite leading the fossorial mode of life, the mandarin vole seems to have no marked morphological adaptations for that. The female mandarin voles, which combine pregnancy with lactation and have to obtain food by excavating soil, are likely ex- posed to a strong energetic problem. Thus, we have proposed the cooperative breeding system with the help of male as well as older young to be supported as an adaptation (possibly, preadaptation) to the fossorial mode of life (Smorkatcheva, 1999). The performing of most of energetically expensive works, i.e. burrow construction, by male and weaned young might result in improving female physical condition, increasing her productivity and/or longevity. Actually, the digging time as well as frequency of bringing food or nest material into the nest were found to be significantly greater for males than for females (Smorkatcheva, 2003). The preliminary observations showed that the older young demonstrate all direct (brooding, grooming and retrieving) and indirect (nest material and food providing and digging) parental behaviors (Zorenko et al. 1994; Smorkatcheva, 2002). However, their relative investments in different activities were unknown. We have predicted offspring to contribute more than reproductive females to digging (Smorkatcheva, 2003). More specifically, the reproductive female should gain from the offspring's labor only if helpers do not consume all the food the group obtains due to their help. Ideally, this hypothesis should be proved under field conditions by estimation the balance between the resources furnished and consumed for each animal. However, data from captive colonies may provide some insights into these problems: we can compare the eating / digging rate between reproductive female and other members of group.

The goal of this study was to compare the contributions of different sex and age categories of individuals to the following behaviors: nest-residence, digging, bringing objects from the aboveground into the burrow, and eating. We observed mandarin voles living as family groups of 4 up to 11 individuals in the settings, which imitated a tunnel system with several chambers and exits leading to "aboveground".

\section{Material and Methods}

\section{Animals and housing}

Animals used in these experiments were laboratoryreared descendants of stock originally captured in Buryatia (South Siberia) in 1990-2002. All animals were maintained on 16L: 8D photoperiod (light on at $0700 \mathrm{~h}$ ). Carrots and oats were provided at lib. Additionally, oat shoots, willow twigs and sunflower seeds were provided in small amounts. The toilet paper served as nest material. Voles in the breeding colony were housed in glass aquariums ( 25 by 50 by $30 \mathrm{~cm}$ ) half-filled with wood shavings.

A week before the beginning of observation, a study group was placed in a setting which represented a system of glass tunnels $(40 \times 450 \times 50 \mathrm{~mm})$ linking 3 chambers $(15 \times 18 \times 10)$. Chambers served as a nest and food stores. One or two opening allowed animals to exit from the tunnel system "aboveground" — into the glass arena 
Table 1. Age limits and reproductive characteristics of the age stages in male and female mandarin voles.

\begin{tabular}{|c|c|c|c|}
\hline stage & age (days) & females & males \\
\hline I & $23-35$ & $\begin{array}{l}\text { Show vaginal estrus when exposed to a strange male. } \\
\text { Non-fertile }\end{array}$ & Non-fertile \\
\hline II & $36-47$ & \multirow{2}{*}{$\begin{array}{l}\text { Show vaginal estrus when exposed to a strange male. } \\
\text { Fertile }\end{array}$} & Non-fertile \\
\hline III & $48-60$ & & $\begin{array}{l}\text { Non-fertile, but some males are able to induce vaginal } \\
\text { estrus in females. In nature, apparently some disperse }\end{array}$ \\
\hline IV & $>60$ & Some individuals show vaginal estrus spontaneously & Fertile. In nature, apparently most disperse \\
\hline
\end{tabular}

(1400 × $390 \times 300 \mathrm{~mm})$ located above burrow system. The floor of the "aboveground" compartment was covered by wood shavings. The food as well as nest material was put at lib into the "aboveground" compartment. We were able to observe voles everywhere except a nest chamber, which usually was filled up by the nest material.

Immediately before introduction of a group into an observation setting members of group were marked by cutting the fur on different parts of body or/and by cutting tails, thus providing a unique mark. Marks were refreshed after each molt.

\section{Behavioral observations}

Each group was under study during 2-4 months, throughout which time groups were typically observed once a week for 100 -min period between 9.00 and 12.00 p.m. The observer was able to record behavioral acts of up to 5 animals during the same observation period.

Seven behaviors that had an appreciable duration were categorized as state behaviors and were collected by scan sampling (Altmann, 1974). Scan samples were taken at 1-min intervals, providing 100 data-points for each individual per an observation period.

For other seven behaviors that did not have appreciable duration (the event behaviors) a number of occurrences per 100-min period was recorded. These were different types of interaction between individuals and bringing objects (food or nest material) into the burrow from the "aboveground".

For the purpose of this work the data on only three state behaviors (nest-residence, digging and eating) and one event behavior (bringing objects) were used. Only the data for families with unweaned pups (1-22 days) were included. Overall, the behavioral data for 40 individuals from 7 family groups based on 39 observation periods were included.

\section{Data analysis}

Non-reproductive individuals were divided into four age groups to reflect the physiological changes during sexual maturation both in males and females (Zorenkoet al., 1994; Smorkatcheva, 2002) (Tab. 1), providing 8 sex-age - categories (daughters at stages I-IV, sons at stages I-IV). Other two categories constituted mothers and fathers.
Digging/eating index (D/E) was calculated for each individual for each observation period by dividing the number of scans spent in digging be the number of scans spent in eating.

As most variables weren't distributed normally, the Mann-Whitney U test was used to assess the significance of differences between age-sex categories. Statistical significance was indicated in all cases by $\mathrm{p}<0.05$.

\section{Results}

\section{Nest residence}

Fathers spent a significantly greater number of scans than did mothers in the nest (Tab. 2; Fig. 1). For offspring at stage I, there were no sex differences in the number of scans spent in the nest. Their nest-residence measures were similar to one of fathers and greater (statistically significantly for daughters) than one of mothers (Tab. 2). Nest-residence time slightly declined in female offspring and, by contrary, slightly increased from stage I to III sons (Fig. 1). As a result of this tendency, daughters at stage III spent in nest significantly greater number of scans than did males at the same stage (Fig. 1) and than did their fathers. Sons at stage III spent in nest significantly greater number of scans, than did their mothers (Tab. 2). In daughters at stage IV this measure increased whereas in even-aged sons, on the contrary, it decreased (Fig. 1). All age differences in nest-residence were non-significant. Therefore, in the oldest age category the direction of sex differences alternated though their level was not significant. Daughters spent significantly greater number of scans in nest than did their mothers (Tab. 2). Overall, sons spent a greater number of scans than did their mothers in the nest (Tab. 2). All other differences were not statistically significant. Thus, among 10 sex-aged categories, fathers, sons at stages II-III and daughters at stage IV demonstrated the greatest contribution to nest-residence.

\section{Digging}

Fathers tended to spend the greater number of scans engaged in digging than did mothers, though this difference did not attain the level of significance (Tab. 2). Across all ages of offspring the number of scans spent in digging was greater in females than in males (Fig. 2). Sex 
Table 2. Statistical behavioral comparisons between female and male reproductive mandarin vole, between weaned offspring and their mother, and between weaned offspring and their father.

\begin{tabular}{|c|c|c|c|}
\hline behavior & class of animals & & $P$ \\
\hline \multirow{13}{*}{ Nest-residence } & fathers & 0.009 & - \\
\hline & daughters at stage: & & \\
\hline & I & 0.038 & 0.759 \\
\hline & III & 0.589 & 0.168 \\
\hline & III & 0.935 & 0.036 \\
\hline & IV & 0.048 & 0.738 \\
\hline & all stages & 0.101 & 0.140 \\
\hline & sons at stage: & & \\
\hline & I & 0.098 & 0.912 \\
\hline & III & 0.072 & 0.975 \\
\hline & III & 0.012 & 0.426 \\
\hline & IV & 0.503 & 0.354 \\
\hline & all stages & 0.016 & 0.835 \\
\hline \multirow{13}{*}{ Digging } & fathers & 0.082 & - \\
\hline & daughters at stage: & & \\
\hline & I & 0.151 & 0.021 \\
\hline & III & 0.396 & 0.638 \\
\hline & III & 0.147 & 0.948 \\
\hline & IV & 0.311 & 0.723 \\
\hline & all stages & 0.558 & 0.238 \\
\hline & sons at stage: & & \\
\hline & I & 0.003 & $<0.001$ \\
\hline & II & 0.109 & 0.016 \\
\hline & III & 0.062 & 0.012 \\
\hline & IV & 0.023 & 0.002 \\
\hline & all stages & $<0.001$ & $<0.001$ \\
\hline \multirow{13}{*}{$\begin{array}{l}\text { Bringing } \\
\text { objects into } \\
\text { the burrow }\end{array}$} & fathers & 0.011 & - \\
\hline & daughters at stage: & & \\
\hline & I & 0.334 & 0.108 \\
\hline & II & 0.080 & 0.520 \\
\hline & III & 0.602 & 0.134 \\
\hline & IV & 0.014 & 0.930 \\
\hline & all stages & 0.042 & 0.183 \\
\hline & sons at stage: & & \\
\hline & I & 0.808 & 0.093 \\
\hline & II & 0.261 & 0.311 \\
\hline & III & 0.138 & 0.008 \\
\hline & IV & 0.735 & 0.041 \\
\hline & all stages & 0.926 & 0.005 \\
\hline
\end{tabular}

Table 2 (continued).

\begin{tabular}{|c|c|c|c|}
\hline behavior & class of animals & & $\mathrm{P}$ \\
\hline \multirow{13}{*}{ Eating } & fathers & $<0.001$ & - \\
\hline & daughters at stage: & & \\
\hline & I & 0.007 & 0.302 \\
\hline & II & 0.254 & 0.003 \\
\hline & III & 0.200 & 0.018 \\
\hline & IV & 0.055 & 0.072 \\
\hline & all stages & 0.010 & 0.004 \\
\hline & sons at stage: & & \\
\hline & I & 0.006 & 0.574 \\
\hline & II & 0.017 & 0.574 \\
\hline & III & 0.038 & 0.489 \\
\hline & IV & 0.009 & 0.895 \\
\hline & all stages & $<0.001$ & 0.864 \\
\hline \multirow{13}{*}{$\begin{array}{l}\text { Digging: } \\
\text { eating rate }\end{array}$} & fathers & $<0.001$ & - \\
\hline & daughters at stage: & & \\
\hline & I & 0.948 & 0.016 \\
\hline & II & 0.131 & 0.070 \\
\hline & III & 0.030 & 0.305 \\
\hline & IV & 0.065 & 0.232 \\
\hline & all stages & 0.057 & 0.020 \\
\hline & sons at stage: & & \\
\hline & I & 0.075 & 0.003 \\
\hline & II & 0.458 & 0.008 \\
\hline & III & 0.597 & 0.006 \\
\hline & IV & 0.391 & $<0.001$ \\
\hline & all stages & 0.122 & $<0.001$ \\
\hline
\end{tabular}

differences were statistically significant for all age categories but the youngest ones. Independent of their age, sons, on average, spent more scans in digging than did their parents (Tab. 2); there were statistically significant differences between males at stage I-IV and fathers, and between males at stage II-III and mothers. When all age categories were pooled, the differences between sons and both parents were also significant (Tab. 1). There were not significant differences in the number of scans spent in digging between daughters (independently of their age) and mothers (Tab. 2), though on average this measure in daughters at stage III was twice as that in mothers. The number of scans spent in digging was significantly lesser in daughters at stage I than in fathers, whereas no difference was evident between older daughters and fathers in this measure (Fig. 2; Tab. 2). When data for all age stages were pooled, daughters did not differ from neither father nor mother. Thus, fathers as well as older (at stages II-IV) daughters seem to play the major role in burrow construction and maintenance. The contribution of sons to this activity was miserable. 


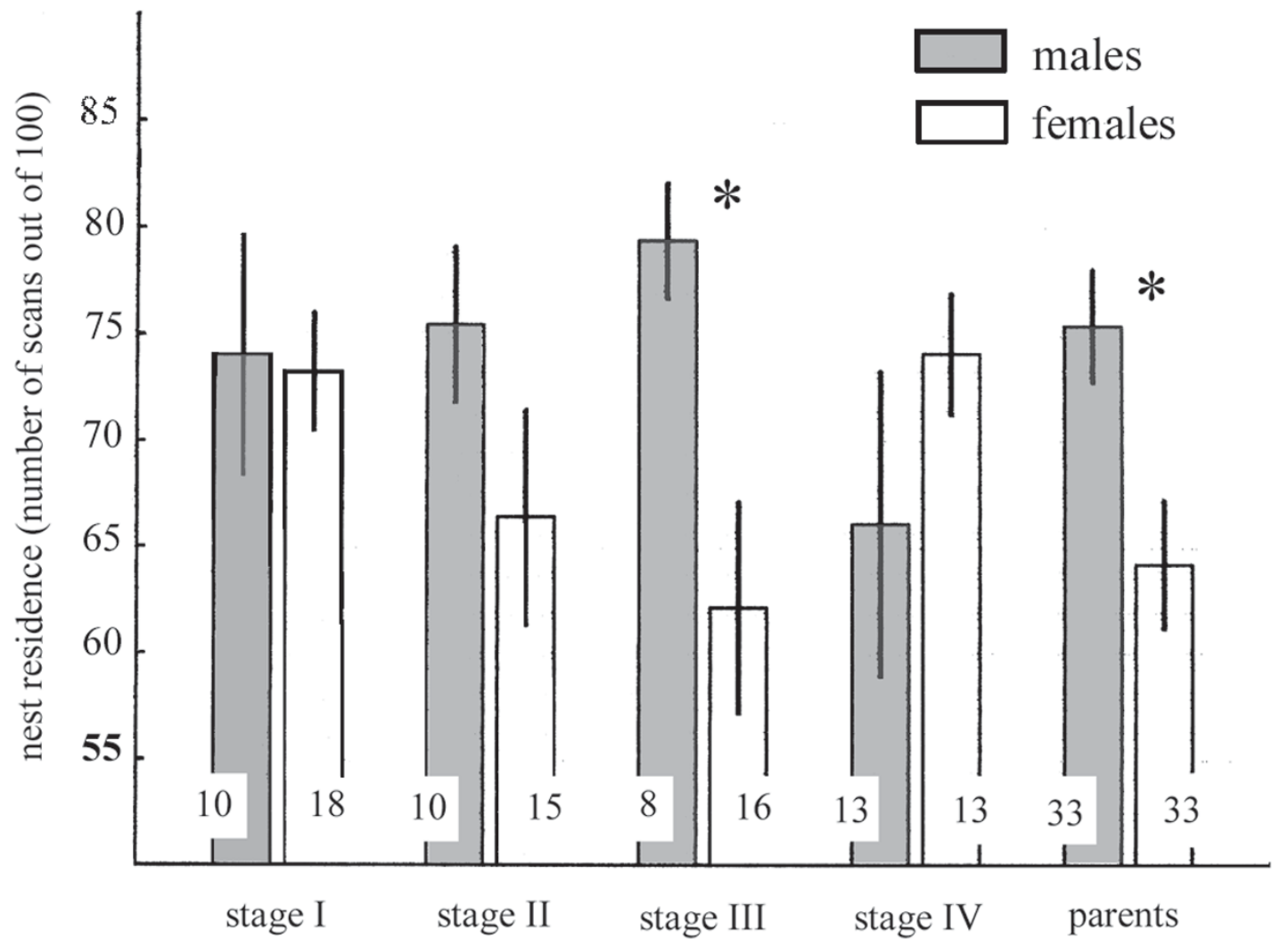

Figure 1. Nest residence (number of scans out of 100) by parents and offspring of different age/sex categories $(*$, significant sex difference, $\mathrm{p}<0.05$ ). Error bars represent $1 \mathrm{SE}$. The figures at the base of each bar are the numbers of observations.

Bringing objects to the burrow from the aboveground

Among parents, fathers brought objects from the surface to the burrow almost 4 times as often as mothers did (the difference was highly significant, Tab. 2). For sons, there were no differences in the frequency of bringing between any two categories. Sons did not differ from mothers by this measure at any age stage, nor when data for all ages were pooled (Fig.3; Tab. 2). On average, the frequency of bringing was much lower in sons at each age stage than in fathers (Fig. 3), but only for sons at stages III-IV these differences were significant (Tab. 2). Daughters at stages I-III did not differ significantly from their parents, or from brothers (Fig.3; Tab. 2). Daughters at stage IV brought objects more frequently than any other categories of offspring, and much more frequently, than mothers (Fig. 3; Tab. 2). Thus, both fathers and daughters older 60 days contributed to food and nest material transport more than other members of family groups.

\section{Eating}

Among parents as well as among offspring females ate more than did males. Sex differences were signifi- cant for parents and for offspring at stages II (Fig. 4). The number of scans mothers spent in eating were especially great, about 3 times as great as males of any categories (all differences between mothers and males were significant). For sons, there were no changes in this measure with age (Fig. 4), and there were no differences between any age categories of sons and fathers (Tab. 2). In daughters, rate of eating slightly increased at stage II and exhibited decline at stages III-IV (age differences were not significant) (Fig. 4). Daughters at each stage ate lesser than did mothers, and these differences were significant for all age categories of daughters, overall (Tab. 1).

\section{Digging/eating rate (D/E index)}

$\mathrm{D} / \mathrm{E}$ index was much greater in fathers than in mothers (Tab. 2). Offspring demonstrated the same direction of sex difference (Fig. 5; Tab. 2) though it was significant only when all ages were pooled $(Z=3.04 ; p=0.020)$. Independent of the stage, sons had a lower D/E index than their fathers had (the difference is significant for all stage) and did not differ from their mothers in this measure (Fig. 5; Tab. 2). In daughters at stage I D/E index was significantly lesser than one in fathers, whereas at stages III and IV as well as in daughters overall it 


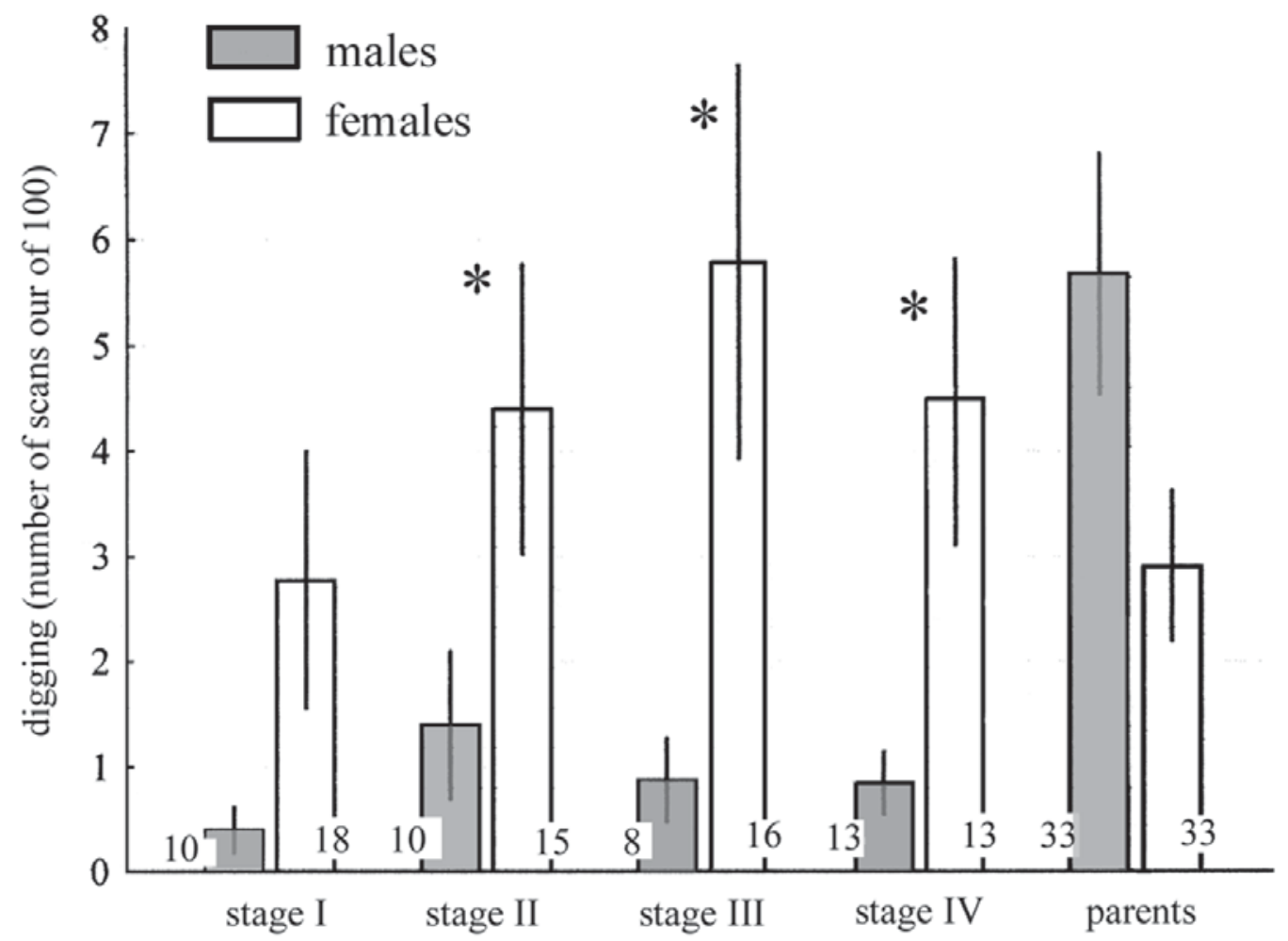

Figure 2. Contributions to digging (number of scans out of 100) by parents and offspring of different age/sex categories (*, significant sex difference, $\mathrm{p}<0.05$ ). Error bars represent $1 \mathrm{SE}$. The figures at the base of each bar are the numbers of observations.

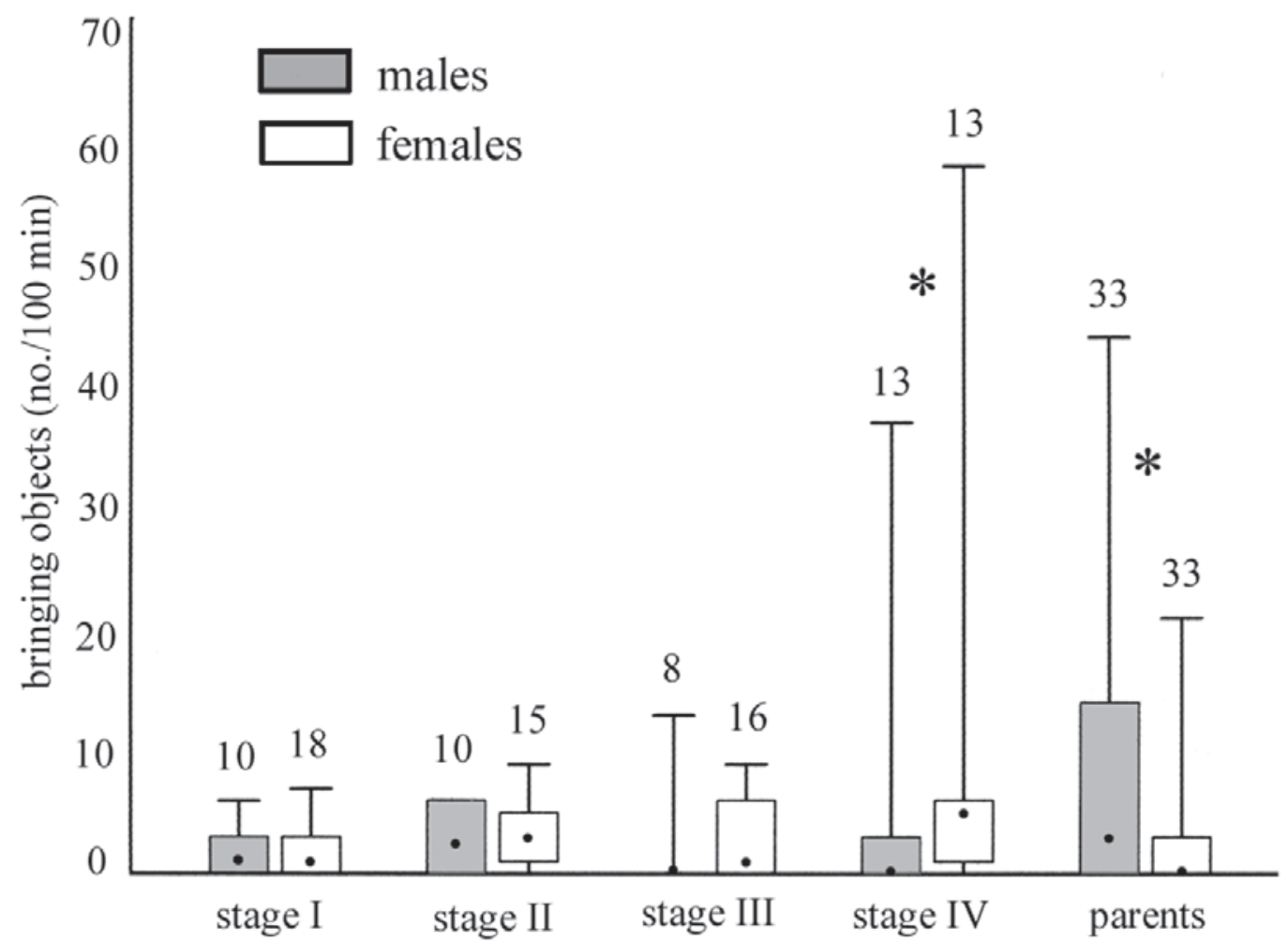

Figure 3. Frequency of bringing objects into the burrow from "aboveground" (number of occurrences per 100-min period) by parents and offspring of different age/sex categories $(*$, significant sex difference, $p<0.05)$. Medians, interquartile ranges and limits are shown. The figures above each bar are the numbers of observations. 


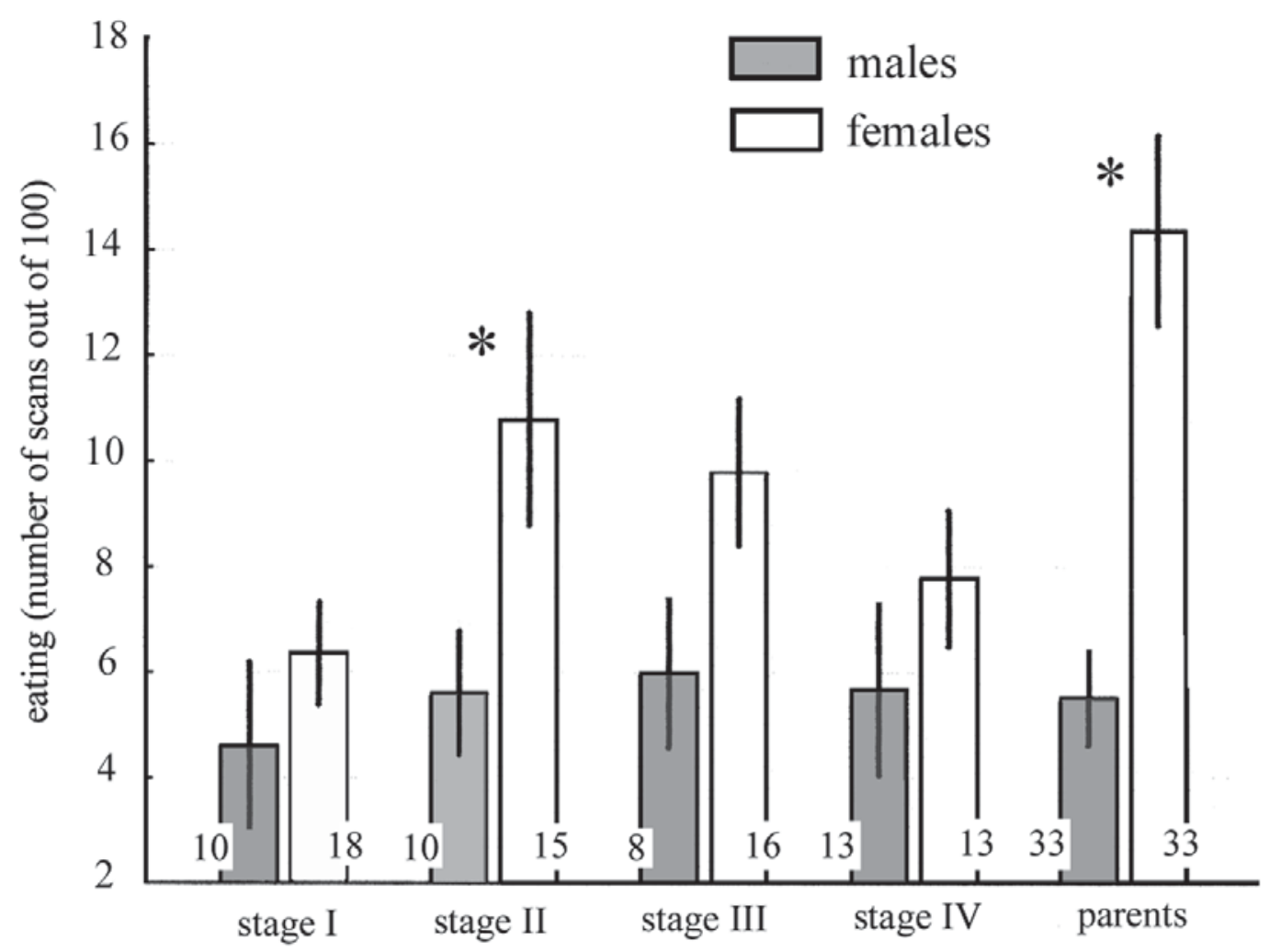

Figure 4. Eating (number of scans out of 100) by parents and offspring of different age/sex categories (*, significant sex difference, $\mathrm{p}<0.05$ ). Error bars represent $1 \mathrm{SE}$. The figures at the base of each bar are the numbers of observations.

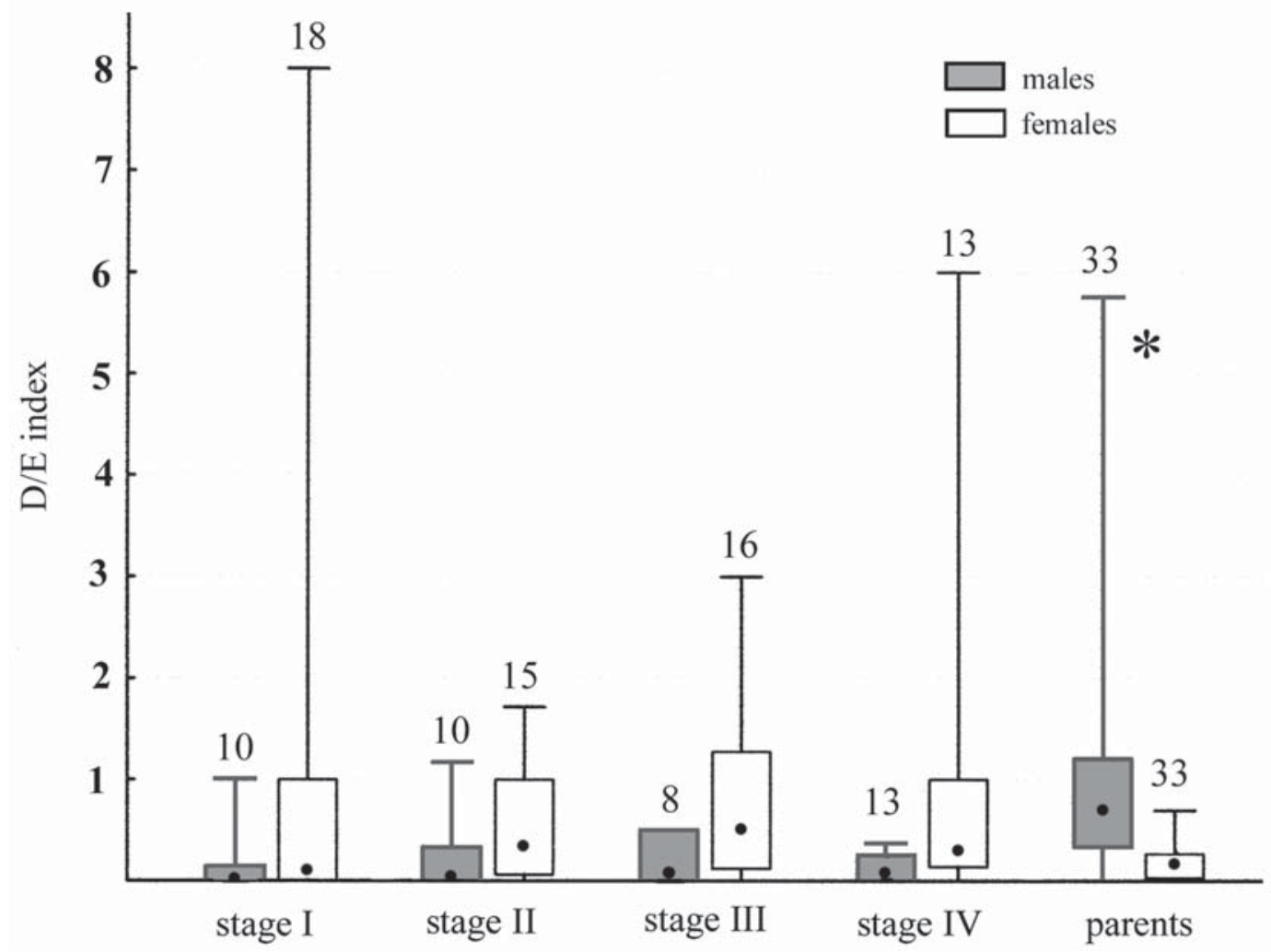

Figure 5. Digging/eating indexes in parents and offspring of different age/sex categories $(*$, significant sex difference, $\mathrm{p}<0.05)$. Medians, interquartile ranges and limits are shown. The figures above each bar are the numbers of observations. 
was greater than one in mothers (this difference reached the level of significance only at stage III) (Fig. 5; Tab. 2).

\section{Discussion}

This study revealed that all individuals in the mandarin vole family participate in all analyzed activities. However, there were strong quantitative differences among group members in the contribution to these behaviors.

In breeding groups fathers seem to play the major role in the most expensive (in terms of energy or risk) forms of labor, as burrow construction and maintenance and transporting food and nest material. They also were, along with young males, the primary baby-sitters. In comparison with older daughters, which participate extensively in the maintenance activities too, fathers ate lesser and consequently, their net contribution appears to be greater.

In this study reproductive males spent significantly more time in the nest than did reproductive females. In our recent investigation of parental care in the adult mandarin voles we could not find significant sex differences in nest-residence (Smorkatcheva, 2003). The earlier study differed in several respects: (i) voles were observed in small cages; 2) pairs reared their first litter; 3) the observed families did not include individual other than parents. Further research is needed to determine which factors are responsible for this discrepancy. However, the relative amount of indirect parental care is unlikely to depend of the same factors.

The relative investments of offspring to different activities were influenced primarily by their sex and, to some extent, by their age.

Young voles at stage I spent a lot of time in the nest. They contributed little to digging as well as bringing objects from aboveground. At this stage sexual differences were expressed slightly, but daughters tended to dig more than sons, and spent almost as much time in digging as their mothers did. Nevertheless, it unlikely that offspring under 35 days do provide significant help to mother by participating in tunnel construction as have been suggested (Smorkatcheva, 1999, 2003). Though weaned at about 21-23 days, mandarin voles seem to be very infantile, both physically and behaviorally, at least up to 30-35 days. In nature, offspring at this stage are hardly able to survive independently, without older individuals.

The degree of differences between sons and daughters in the amount of nest-residence, digging, eating and bringing objects increased with the age. The directions of sex differences in nest-residence were age-specific: among offspring of 36-60 days age males spent more time in nest than females did, whereas after 60 days (by which age both sexes attain reproductive maturity) the reverse situation was observed. Daughters were engaged more than sons were in other behaviors, though the degrees of these differences were age-dependent. Overall, older daughters are likely to be the primary participants in tunnel constructing and maintenance as well as in bringing food and nest material. On average, their contribution to "work" was greater than their mother's contribution, while the time they were engaged in eating was much lesser than one in their mother. This data provide evidence that phylopatric young females perform some excess workload (with respect to their own needs) to be used up, potentially, by reproductive female. Unlike daughters, sons were revealed to play rather passive role in burrow constructing and transport of objects. Their participation in alloparental care seems to be restricted by such inexpensive forms as brooding and grooming.

Strong sex differences in the degree of maintenance activities could not be explained in the framework of indirect fitness benefits hypotheses (Hamilton, 1964), because male and female offspring should have the same level of relatedness to their younger sibs. These forms of helping are unlikely be unselected by-product of innate individual's parental response (Jemieson, 1989) or simply by-product of non-synchronous hormonal processes, accompanying sexual maturation, because they are costly. The only hypotheses consistent with the revealed sex bias in the level of labor performed, seems to be one which involves benefits of delayed reciprocity or group augmentation (Ligon \& Ligon, 1978; Woolfenden \& Fitzpatric, 1978; Brotherton, 2001). This hypothesis would predict that individuals that are most likely to associate with the pups in the future should help most. Actually, the field data provide evidence for the natal dispersion of male mandarin voles to be obligate whereas some of daughters may reproduce staying at natal territory (Smorkatcheva, 1999). The similar sex differences in the feeding pups, corresponding to the female tendency to philopatry, have been found in brown hyaenas Hyaena brunnea (Owens \& Owens, 1984) and meerkats Suricata suricata (Brothertonet al., 2001). By helping pups and their mother, female helpers potentially have more to gain by increasing the number of potential future helpers.

Regarding tunnel construction, another ultimate explanation based on sex-biased dispersal may account for a high rate of digging in daughters and laziness of sons. Our field data indicate that burrows remain and are in use for the long time (often for months), though they may grow up and change their shape (Smorkatcheva et al., 1990). The contribution of young individual to burrow construction and maintenance would be its parental, not alloparental investment should it attain a breeding position in this burrow. Apparently, only daughters, not sons, have this chance. If this is true, then we can expect the rate of digging in female offspring (unlike the rate of digging in reproductive male) would not depend on the presence of their mother as well as pups.

Unlike digging and bringing, helping behavior in the form of baby-sitting does not seem to be promoted in the mandarin vole by future benefits of delayed reciprocity or group augmentation, because, overall, there weren't significant sex differences in the amount of nest-residence. Apart from this conclusion, our data do not refute nor confirm any other explanation put forward to ac- 
count for helping behavior. From the literature data (Wang, 1991, cited by Solomon \& Getz, 1997; Gubernick \& Laskin, 1994), it seems to be unlikely that alloparental behavior in rodents may be a means of gaining parental skills that are of great importance for the survival of pups (Scutch, 1961; Lancaster, 1971). Two general questions remain to be answered.

1) Whether baby-sitting (brooding, grooming or, may be, guarding) performed by older offspring (and by both parents, too) is associated with any costs? Apparently, this form of helping is not so expensive as digging or bringing food. The time each member of family spends in nest may simply correspond to its physiological need. It is possible that the observed age-related changes in duration of nest residence are the results of the hormonal shifts, accompanying sexual maturation or/and (in male offspring) dispersal phase. The possible way to verify this proposition in laboratory is to investigate the effect of social environment on the time each member of group spends in nest. The design of such experiments should allow us to distinguish between socially coordinated behavior and cooperated behavior (Clutton-Brock, 2002).

2) Whether older offspring gain indirect benefits from their assistance in baby-sitting? Helpers may accrue their indirect fitness by freeing parental energy to enable breeders to produce the next litter sooner (compensatory parental care) or by increasing the number or quality of pups produced (supplemental parental care) (Solomon \& Getz, 1997). The results of several laboratory studies in voles provide some support for these hypotheses. Both in pine voleMicrotus pinetorum (Fried, 1987, cited by Solomon \& Getz, 1997) and in prairie voles M. ochrogaster (Solomon, 1991) fathers appear to benefit most (in terms of increased time outside the nest) from the presence of alloparents. In $M$. pinetorum maintained in outdoor enclosures, families with three helpers had shorter interlitter intervals than families with 0-2 helpers (Powell \& Fried, 1992). Similarly, in prairie voles the presence of alloparents resulted in more rapid production of the subsequent litter (Solomon, 1991). Neither presence of alloparents nor increased number of alloparents affected litter size in both these species (Solomon, 1991; Powell \& Fried, 1992) as well as in Mongolian gerbils Meriones unguiculatus (French, 1994). However, positive effect of alloparents on pup growth has been found when prairie voles were housed at environmentally challenging temperatures (Solomon, 1991). Whether the same is true for the mandarin voles, remain to be revealed.

To summarize, this study provides the further evidence that males extensively participate in costly activities. This contribution may be of great importance for female reproductive success, though this proposition is difficult to prove. The second conclusion which arises from our results, is their inconsistency with the hypothesis involving indirect benefits helpers gain by digging as one of the factors supporting cooperative breeding in the subterranean voles (Smorkatcheva, 1998, 2003). Clearly, it is not the case in the mandarin vole. Thus, the cooperative breeding in this species seems to evolve via individual selection for delayed dispersal, as it was argued forMicrotus pinetorumby Powell \& Fried (1992).

ACKNOWLEDGMENTS. We are grateful to A. Mironov for construction of observation settings and to S. Afanasiev for the help in statistics. The research was partially supported by grants RFBR 02-04-49273a and RFBR 04-04-63050k

\section{References}

Altmann J. 1974. Observational study of behaviour: sampling methods // Behaviour. Vol.49. No.3-4. P.227-267.

Bennett N.C. \& Jarvis J.U.M. 1988. The social structure and reproductive biology of colonies of the mole-rat, Cryptomys damarensis (Rodentia: Bathyergidae) // Journal of Mammalogy. Vol.69. No.2. P.209-302.

Bennett N.C. 1989. The social structure and reproductive biology of the common mole-rat, Cryptomys hottentotus hottentotus and remarks on the trends in reproduction and sociality in the family Bathyergidae // Journal of Zoology, London. Vol.219. No.1. P.45-59.

Brotherton P.N.M., Clutton-Brock T.H., O'Riain M.J., Gainor D., Sharpe L., Kansky R. \& McIlrath G.M. 2001. Offspring food allocation by parents and helper in a cooperative mammal // Behavioural Ecology. Vol.12. No.5. P.590-599.

Burda H. 1990. Constraints of pregnancy and evolution of sociality in mole-rats with special reference to reproductive and social patterns in Cryptomys hottentotus (Bathiergidae, Rodentia) // Zeitschrift für zoologische Systematik und Evolutionsforschung. Bd.28. Hf.1. P.26-39.

Burda H., Honeycutt R.L., Rodney L., Begall S., LockerGruetjen O. \& Scharff A. 2000. Are naked and common mole-rats eusocial and if so, why? // Behavioural Ecology and Sociobiology. Vol.47. No.5. P.293-303.

Clutton-Brock T.H. 2002. Kin selection and mutualism in cooperative vertebrates // Science. Vol.296. No.5565. P.69-72.

Evdokimov N.G. 2001. [Population Ecology of the Molevole]. Ekaterinburg: Ural'skoe Otdelenie Rossiiskoi Akademii Nauk. 142 p. [in Russian].

Fitzgerald R.W. \& Madison D.M. 1983. Social organization of a free-ranging population of pine vole, Microtus pinetorum // Behavioural Ecology and Sociobiology. Vol.13. No.4. P.183-187.

Gaston A.J. 1978. The evolution of group territorial behavior and cooperative breeding // American Naturalist. Vol.112. No.988. P.1091-1110.

Gubernick D.J.\& Laskin B. 1994. Mechanisms influencing sibling care in the monogamous biparental California mouse, Peromyscus californicus // Animal Behaviour. Vol.48. No.5. P.1235-1237.

Hamilton W.D. 1964. The genetic evolution of social behaviour // Journal of the Theoretical Biology. Vol.7. No.1. P.1-52.

Jamieson I.G. 1989. Behavioral heterochrony and the evolution of bird's helping at the nest: an unselected consequence of communal breeding? // American Naturalist. Vol.133. No.3. P.394-406.

Jarvis J.U.M. 1981. Eusociality in a mammal: cooperative 
breeding in naked mole-rat colonies // Science. Vol.212. No.4494. P.571-573.

Krebs J.R. \& Davies N.B. 2000. An Introduction to Behavioural Ecology. Third Edition. Oxford: Blackwell Science. $140 \mathrm{p}$.

Lacey E.A. 2000. Spatial and social systems of subterranean rodents // Lacey E.A., Patton J.L. \& Cameron G.N. (eds.). Life Underground. The biology of Subterranean Rodents. Chicago \& London: Chicago University Press. P.257296.

Lancaster J.B. 1971. Play-mothering: the relations between juvenile females and young infants among free-ranging vervet monkeys (Cercopithecus aethiops) // Folia Primatologia. Vol.15. No.3-4. P.161-182.

Ligon J.D.\& Ligon S.H. 1978. Green woodhoopoes: lifehistory traits and sociality // Stacey P.B. \& Koenig W.D. (eds.). Cooperative Breeding in Birds: Long-term Studies of Ecology and Behavior. Cambridge: Cambridge University Press. P.33-65.

Moolman M., Bennet N.C. \& Schoeman A.S. 1998. The social structure and dominance hierarchy of the highveld mole-rat Cryptomys hottentotus pretoriae (Rodentia: Bathyergidae) // Journal of Zoology, London. Vol.246. No.2. P.193-201.

Owens D.D.\& Owens M.J. 1984. Helping behaviour in brown hyaenas // Nature. Vol.308. No.5962. P.843-845.

Powell R.A. \& Fried J.J. 1992. Helping by juvenile pine voles (Microtus pinetorum), growth and survival of younger siblings, and the evolution of pine vole sociality // Behavioural Ecology. Vol.3. No.4. P.325-333.

Skutch A.F. 1961. Helpers among birds // Condor. Vol.63. No.3 P.198-226.

Smorkatcheva A. 1999. The social organization of the mandarine vole, Lasiopodomys mandarinus, during the reproductive period // Zeitschrift für Säugetierkunde. Bd.64.
Hf.6. P.344-355.

Smorkatcheva A.V., Aksenova, T.G. \& Zorenko T.A. 1990. [The ecology of Lasiopodomys mandarinus (Rodentia, Cricetidae) in the Transbaikal area] // Zoologicheskii Zhurnal. T.69. No.12. P.115-124 [in Russian, with English summary].

Smorkatcheva A.V. 2002. [Effect of social environment on social maturation and reproduction in captive female mandarin voles, Lasiopodomys mandarinus] // Zoologicheskii Zhurnal. T.81. No.8. P.991-998 [in Russian, with English summary].

Smorkatcheva A. 2002. Social system in the mandarin vole Lasiopodomys mandarinus: results of field and laboratory studies // Le Boulengé E. (ed.). Rodens and Spatium. Eighth International Conference, Louvain-la-Neuve, July 22-26, 2002. P.101.

Smorkatcheva A.V. 2003. Parental care in the captive mandarin vole, Lasiopodomys mandarinus // Canadian Journal of Zoology. Vol. 81. No.8. P.1339-1345.

Solomon N. G. 1991. Current indirect fitness benefits associated with philopatry in juvenile prairie voles // Behavioural Ecology and Sociobiology. Vol.29. No.4. P.277-282.

Solomon N.G. \& Getz L.L. 1997. Examination of alternative hypotheses for cooperative breeding in rodents. // Solomon N.G. \& French T.A. (eds.). Cooperative Breeding in Mammals. New York: Cambridge University Press. P.199-230.

Woolfenden G.E.\& Fitzpatric J.W. 1978. The inheritance of territory in group-breeding birds // Bioscience. Vol.28. No.2. P.104-108.

Zorenko T.A., Smorkatcheva A.V. \& Aksenova T.G. 1994. [Reproduction and postnatal ontogenesis of mandarin vole Lasiopodomys mandarinus (Rodentia, Arvicolinae)] // Zoologicheskii Zhurnal. T.73. No.6. P.120-129 [in Russian, with English summary]. 